\title{
Surface water quality assessment of the main tributaries in the lower São Francisco River, Sergipe
}

\section{Avaliação da qualidade da água superficial dos principais afluentes do baixo rio São Francisco em Sergipe}

\author{
Fábio Brandão Britto ${ }^{1}$, Anderson Nascimento do Vasco ${ }^{1}$, Antenor de Oliveira Aguiar Netto ${ }^{2}$, \\ Carlos Alexandre Borges Garcia ${ }^{2}$, Gilsia Fabiane Oliveira Moraes ${ }^{1}$ and Marinoé Gonzaga da Silva ${ }^{1}$ \\ ${ }^{1}$ Instituto Federal de Sergipe, São Cristóvão, SE, Brasil \\ ${ }^{2}$ Universidade Federal de Sergipe, São Cristóvão, SE, Brasil \\ E-mails: brandaobritto@hotmail.com (FBB), anderovasco@yahoo.com.br (ANV), antenor.ufs@gmail.com (AOAN), cgarcia@ufs.br (CABG), \\ gislane.rocha.18@gmail.com (GFOM), marinoegonzaga@gmail.com (MGS)
}

Received: April 23, 2017 - Revised: April 10, 2018 - Accepted: April 30, 2018

\begin{abstract}
Contamination of water body by diffuse and point sources in springs has caused concerns mainly due to restrictions on its quality. The problem becomes more serious when contamination affects water for human consumption, as occurs in the river São Francisco, which supplies several municipalities of Sergipe. In this sense, the objective of the study was to evaluate water quality in eleven tributaries of the São Francisco river in its low course in the period from 2013 to 2014, in order to subsidize decision making by public management bodies operating in the region. For this purpose, it was used the Water Quality Index (WQI) and the Trophic State Index (TSI), as well the hierarchical grouping techniques associated to the samples to compare the different causes of contamination of each source. The lowest WQI values were observed in the rivers Betume and Jacaré and they were associated with high concentrations of coliforms related to the disposal of domestic effluents from the riverside cities. It was observed a tendency to eutrophication in the Jacaré stream, Santo Antônio, Pilões, Papagaio and Capivara rivers demonstrated by the high TSI in the rainy season. The results of the cluster analysis were close to their Euclidean distance, and showed that there were similarity relationships between the different water sources related to their parameters of water quality. In this piece of work, we also used the Factor Analysis resulted in the selection of five factors of water quality indicators which are mainly related to mineral content, organic matter, surface runoff and the level of pollution. Thus, it is concluded that the water quality of the São Francisco river tributaries is at a strong tendency towards contamination and that its tributaries need a constant monitoring for the environmental management decisions to be the most adequate for the sustainable survival of the riverside communities.
\end{abstract}

Keywords: Environmental monitoring; Eutrophication; Factorial analysis and clustering.

\section{RESUMO}

A contaminação de corpos d'água por fontes difusas e pontuais em mananciais tem causado preocupações principalmente pelas restrições em sua qualidade. O problema torna-se ainda mais grave quando a contaminação afetar a água destinada ao consumo humano, como ocorre no rio São Francisco, que é a principal fonte de água para abastecimentos de várias cidades do nordeste do Brasil. Neste sentido, o objetivo deste estudo foi avaliar a qualidade da água em onze afluentes do rio São Francisco no seu baixo curso no período de 2013 a 2014, para subsidiar tomadas de decisões por parte de órgãos de gestão pública que atuam na região. Utilizou-se, para isso, o Índice de Qualidade da Água (IQA) e o Índice de Estado Trófico (IET), também foram utilizadas técnicas de agrupamento hierárquico associado as amostras para comparar as diferentes fontes de contaminação de cada manancial. Os menores valores de IQA foram determinados no rio Betume e Jacaré e estão associados a altas concentrações de coliformes provenientes do despejo de efluentes doméstico das cidades ribeirinhas. Observou-se, ainda, uma tendência a eutrofização do riacho Jacaré e dos rios Santo Antônio, dos Pilões, Papagaio e Capivara demonstrada pelo alto IET no período chuvoso. Os resultados da análise de agrupamento de amostras 
apresentaram proximidades com relação a sua distância euclidiana, e isso demonstra que houve relações de similaridade entre os mananciais distintos relacionados a seus parâmetros de qualidade da água. Neste trabalho também foi utilizada a Análise Fatorial que resultou na seleção de cinco fatores indicadores de qualidade da água que estão relacionados, principalmente, com o conteúdo mineral, matéria orgânica, escoamento superficial e grau de poluição. Dessa forma, conclui-se que a qualidade da água dos afluentes do rio São Francisco apresenta indícios de contaminação e que seus afluentes necessitam de um monitoramento constante para as decisões de gestão ambiental sejam as mais adequadas para sobrevivência sustentável das comunidades ribeirinhas.

Palavras-chave: Monitoramento ambiental; Eutrofização; Análise fatorial e agrupamento.

\section{INTRODUCTION}

The contribution of agricultural, urban and industrial pollutants to rivers in various parts of the world have led to the deterioration of water resources. Land use and occupation without planning contribute to anthropogenic actions which cause changes in local water quality and induce its pollution to unacceptable levels (SOUZA; GASTALDINI, 2014). For Massoud (2012), water quality reflects the aggregate effects of various processes which occur along water flow and is influenced by the characteristics of the river basin. Therefore, it is important to evaluate the water quality to suit its respective use (BARRETO et al., 2014).

In this context, water quality problems involve a very broad spectrum within the areas of hydro-environmental study and determination of potential sources of contamination. Among these sources, it can be said that sediment and nutrient transports and the presence of organic matter in the river bed can cause irreversible damage, surpassing the river's self-purification capacity (WITTMAN et al., 2013). All these anthropogenic actions have impacts which are interrelated with the natural processes which occur in the watershed (VASCONCELOS; SOUZA, 2011). In order to have a proper management of water resources, the first step is the monitoring of water quality, to characterize physical and chemical parameters which allow to diagnose the changes caused by anthropic or natural actions, in the use and occupation of the land (BARRETO et al., 2014). Monitoring involves a set of procedures which aims analysing certain characteristics of a system, always correlating to the established goal, which can be either the maintenance or recovery of the water quality. The water quality of water bodies can be investigated from changes in their physical, chemical and biological characteristics related to either anthropic activities or natural phenomena.

Procedures related to water quality monitoring include collecting water samples and obtaining data at specific locations, preferably geo-referenced, found at regular intervals, in order to generate information which can be used to define the present conditions of water quality (OLIVEIRA; CAMPOS; MEDEIROS, 2010). The result of this monitoring is usually associated with a complex set of data which are often difficult to analyse, making it difficult to understand the real conditions of water quality. For this, it can be used statistical techniques which join the parameters analysed and thus provide consolidated information about the water quality of these sources.

When assessing the quality of surface water, we ought to employ methods of easy understanding so that information can be transmitted to users of this resource (FERREIRA et al., 2015; CUNHA et al., 2013). The use of water quality indices has been an alternative to monitor changes (anthropogenic or natural) in water quality along a watershed or time (MORETTO et al., 2012). In this piece of work, the Water Quality Index (WQI) and Trophic State Index (TSI) were used, as well as multivariate statistical techniques with Grouping and Principal Component analysis (GPC), aiming to determine the factors which are causing the deterioration of the quality of the water in springs of the low São Francisco river. It is worth mentioning that this is the first work, in this magnitude, to be developed in the lower São Francisco and which will provide subsidies for decision making by the environmental agencies which work in the region.

\section{MATERIAL AND METHODS}

\section{Study area}

The low course of the São Francisco river is located between the city of Paulo Afonso, state of Bahia and its mouth between the states of Sergipe and Alagoas, it occupies an area of $32,013 \mathrm{~km}^{2}$ and $247 \mathrm{~km}$ in length (MARTINS et al., 2011). The São Francisco river is one of the main sources of water supplies in several cities in northeastern Brazil and its monitoring ought to be carried out in a continuous and integrated manner. In order to evaluate the quality of its water, rivers, streams, dam and drainage channels were monitored during the period of 2013 and 2014, considering the periods of floods and droughts of the studied regions (Figure 1). The surface water quality data for the Capivara, Papagaio, Pilões, Santo Antônio and Jacaré streams were provided by the Technological Research Institute of the State of Sergipe (ITPS) and the Superintendence of Water Resources of the State of Sergipe (SRH), with 4 campaigns, one each semester - two in the dry season and two in the rainy season. The other sources, and more important ones, were monitored in monthly campaigns, totaling 24 in the period from 2013 to 2014.

Table 1 shows the monitored parameters and the analytical methods used. In order to identify the water quality conditions, the Water Quality Index (WQI) was used, which is an empirical form used to give answers about the quality of water, in values ranging from 0 to 100 ; the higher the number, the better the water quality (CETESB, 2008).

The parameters considered for calculating the WQI and its respective weights can be observed in Table 2.

The adopted WQI is an adaptation of the National Sanitation Foundation (NSF) water quality index, and it is determined by the weighted product of the values obtained for the parameters of Table 2 according to Equation 1. 


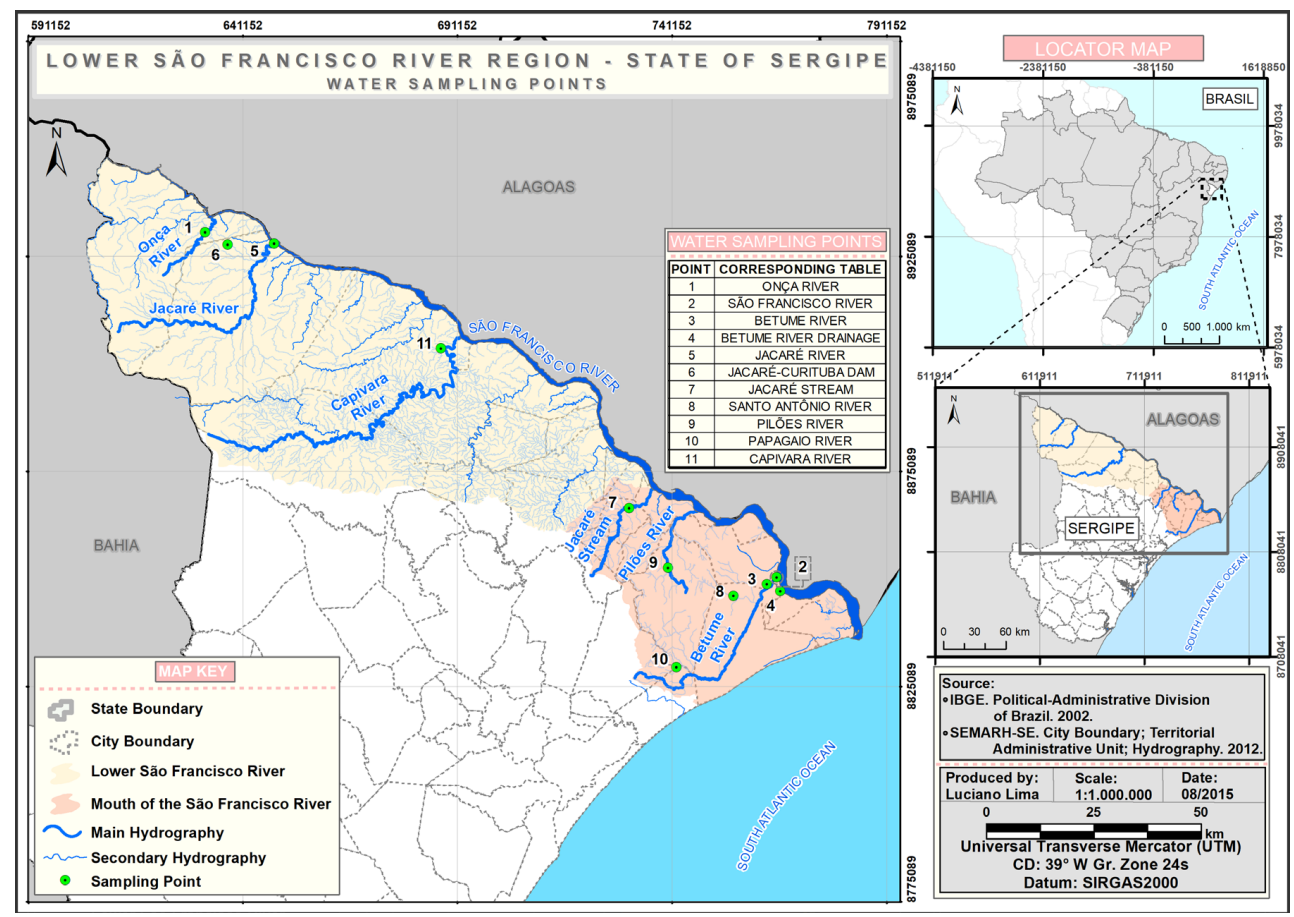

Figure 1. Spatial location of collection points in the lower São Francisco river in Sergipe.

Table 1. Physico-chemical parameters monitored in the lower São Francisco River.

\begin{tabular}{|c|c|c|c|}
\hline Parameters & Methodology & L.Q & Unity \\
\hline OD & SMEWW, 2012, 4500-O C & - & $\mathrm{mg} \mathrm{O}_{2} \mathrm{~L}^{-1}$ \\
\hline Thermophilic Coliforms & SMEWW9221B & - & NMP. $100 \mathrm{~mL}^{-1}$ \\
\hline $\mathrm{pH}$ & SMEWW, 2012, $4500 \mathrm{H}+\mathrm{B}$ & - & - \\
\hline $\mathrm{DBO}$ & SMEWW, 2012, 5210-D & - & $\mathrm{mg} \mathrm{O}_{2} \mathrm{~L}^{-1}$ \\
\hline Temperature & Multiparameter probe HANNA - HI9829 & - & ${ }^{\circ} \mathrm{C}$ \\
\hline $\mathrm{N}$-amoniacal & Ion Chromatography (US EPA 300.0) & 0.039 & $\mathrm{mg} \mathrm{NH} \mathrm{NH}_{3} \mathrm{~L}^{-1}$ \\
\hline Nitrate & Ion Chromatography (US EPA 300.0) & 0.011 & $\operatorname{mg~N} \mathrm{NO}_{3} \cdot \mathrm{L}^{-1}$ \\
\hline Total phosphorus & SMEWW,4500-P E & 0.010 & mg P.L ${ }^{-1}$ \\
\hline Turbidity & SMEWW, 2012, 2130 B & - & $\mathrm{UT}$ \\
\hline STD & SMEWW, 2012, 2510 A & - & mg. $L^{-1}$ \\
\hline Total hardness & SMEWW, 2012, 2340 B & - & $\mathrm{mg} \mathrm{CaCO}{ }_{3} \cdot \mathrm{L}^{-1}$ \\
\hline Chlorophyll-a & Spectrophotometric determination & 0.001 & $\mu g \cdot L^{-1}$ \\
\hline Sulfates & Ion Chromatography (US EPA 300.0) & 0.050 & $\mathrm{mg} \mathrm{SO} \mathrm{S}_{4} \mathrm{~L}^{-1}$ \\
\hline Total iron & AAS & 0.023 & mg Fe. $L^{-1}$ \\
\hline Sodium & AAS & 0.044 & $\mathrm{mg} \mathrm{Na} \cdot \mathrm{L}^{-1}$ \\
\hline Chloride & SMEWW,4500-CL B & 2.420 & $\operatorname{mg~Cl} \cdot \mathrm{L}^{-1}$ \\
\hline Conductivity & Multiparameter probe HANNA - HI9829 & - & $\mu \mathrm{S} . \mathrm{cm}^{-1}$ \\
\hline
\end{tabular}

Table 2. Water quality parameters and their weight.

\begin{tabular}{lc}
\hline \multicolumn{1}{c}{ Water quality parameters } & Weight $(\mathbf{w})$ \\
\hline OD & 0.17 \\
Thermophilic Coliforms & 0.15 \\
pH & 0.12 \\
BOD & 0.10 \\
Water temperature & 0.10 \\
Total Nitrogen & 0.10 \\
Total Phosphorus & 0.10 \\
Turbidity & 0.08 \\
TDS & 0.08 \\
\hline
\end{tabular}

Source: CETESB (2008).
On what:

$$
I Q A=\Pi_{i=1}^{n} q_{i}
$$

WQI = Water Quality Index (WQI); qi = quality of the parameter "i" obtained by the average curve of specific quality; wi = weight assigned to the parameter, due to its importance in quality (0-1). From the calculation, water quality was determined by WQI values ranging from 0 to 100 , according to the ranges indicated in Table 3. The Calrson Trophic State Index (TSI) modified by Lamparelli (2004) was also used, with Equations 2 and 3 established for lotic environments. 


$$
\begin{aligned}
& \operatorname{IET}(C L)=10 x\left[6-\left(\frac{-0.7-0.6 \times \ln (C L)}{\ln 2}\right)\right]-20 \\
& \operatorname{IET}(P T)=10 x\left[6-\left(\frac{-0.42-0.36 x \ln \left(P_{\text {total }}\right)}{\ln 2}\right)\right]-20
\end{aligned}
$$

On what:

$\mathrm{P}_{\text {total }}=$ total phosphorus concentration measured at the water surface, in mg. $\mathrm{L}^{-1} ; \mathrm{CL}=$ the concentration of chlorophyll on the surface of the water, in $\mu \mathrm{g} \cdot \mathrm{L}^{-1}$; For the final calculation of the TSI, the simple arithmetic mean of the Ptotal and CL indices were used, according to Equation 4.

$$
I E T=\frac{I E T\left(P_{\text {total }}\right)+\operatorname{IET}(C L)}{2}
$$

At each monitoring point, the arithmetic averages of the concentrations of total phosphorus and chlorophyll-a were used to determine the annual TSI, and were classified according to Table 4. The use of multivariate analysis techniques to interpret water quality parameters can be used to classify similar groups and to express hydro-chemical responses with similar trends. Among these, clustering allows to classify a set of observation objects into homogeneous classes according to similarities, being used by several researchers from different parts of the world (ANDRADE et al., 2016). According to Nonato et al. (2007), the hierarchical grouping technique associates the samples with each other, and produces a dendogram, in which the similar samples are grouped according to the chosen variables. The smaller the distance between the points, the greater the similarity between the samples. The simplest way to look for clusters in $\mathrm{n}$-dimensional space is to group the pairs of points that are closest to each other, using Euclidean distance, and replace them with a new point located half the distance between them.

The main hierarchical grouping methods are: the UPGMA (Unweighted Pair-Group Method using Arithmetic Averages), the median (or WPGMA) method, the nearest neighbor method, the far-neighbor method, the centroid method, and the Ward minimum variance method. All these operate under the matrix distances, avoiding the original data (CRUZ; FERREIRA; PESSONI, 2011).

Out of all these methods, Ward's minimum variance method is the most recommended because it tends to form approximately equal size groupings due to their minimization of internal variation. It consists of a hierarchical grouping procedure in which the similarity measure is used to join clusters and is calculated as the sum of squares between the two clusters obtained through the variables (HAIR et al., 2005). At each stage, it is combined two clusters which present the smallest increase in the global sum of squares within the clusters. In the last years, several studies have used cluster analysis to assess water quality (LIMA et al., 2015; ROCHA; COSTA, 2015; ROCHA; PEREIRA, 2016).

The large number of variables and springs analyzed in Lower São Francisco have produced data matrices with proportions which are inadequate to interpretation. In order to overcome this situation, a multivariate statistical technique was used, called Cluster Analysis, minimizing such difficulties and being used in several hydrological, hydro-meteorological and hydro-chemical studies (AZHAR et al., 2015; HOSSAIN et al., 2013; SALAH; TURKI; AL-OTHMAN, 2012).
Table 3. Values and classes of water quality WQI.

\begin{tabular}{lc}
\hline \multicolumn{1}{c}{ Category } & Weighting \\
\hline Great & $100 \geq \mathrm{IQA} \geq 80$ \\
Good & $80 \geq \mathrm{IQA}>52$ \\
Acceptable & $52 \geq \mathrm{IQA}>37$ \\
Bad & $37 \geq \mathrm{IQA}>20$ \\
Terrible & $20 \geq \mathrm{IQA}>0$ \\
\hline
\end{tabular}

Source: CETESB (2008).

Table 4. Values and classes of the trophic state TSI.

\begin{tabular}{lc}
\hline \multicolumn{1}{c}{ Category } & Weighting \\
\hline Ultra oligotrophic & IET $\leq 47$ \\
Oligotrophic & $47<$ IET $\leq 52$ \\
Mesotrophic & $52<$ IET $\leq 59$ \\
Eutrophic & $59<$ IET $\leq 63$ \\
Super eutrophic & $63<$ IET $\leq 67$ \\
Hyper eutrophic & IET $>67$ \\
\hline
\end{tabular}

Source: CETESB (2008); Lamparelli (2004).

Principal Component Analysis (PCA) is a multivariate statistical technique which proposes to reduce a set of data which present many interrelated variables with the lowest possible loss of information. The original data are defined in a new set of variables called principal components (LIMA et al., 2011). In order to simplify the interpretation and to preserve its statistical properties, the orthogonal rotation of the factors was applied by the Varimax method, whose objective is to maximize the participation of the variables with greater contribution to each factor, making its loads higher and reducing the participation of variables with minor contributions (FIGUEIREDO FILHO; SILVA JÚNIOR, 2010).

\section{RESULTS AND DISCUSSION}

The use of environmental resources, most of the time, without any planning, causes degradation, compromising the quality of life of future generations. In this context, the use of monitoring tools such as WQI and TSI can collaborate in the control of ecosystems mainly in the lower São Francisco region.

In the rainy season, out of the eleven wells monitored (Figure 2A), approximately 50\% were classified as acceptable, that is, in the border region with a tendency to decrease the WQI. These values may be related to the release of urban pollutants from the riverside cities, which in most cases do not have adequate systems to treat their effluents. Similar results of WQI in the rainy season were obtained by other authors, such as Alves et al. (2012), Andrietti et al. (2016) and Amorim et al. (2016). Among the fountains evaluated in the rainy season, the Betume river presented the lowest water quality being considered "bad", WQI (34). This condition was mainly related to changes in the parameters: thermotolerant coliform with a value above $3.6 \times 10^{5}(\mathrm{MPN})$ and OD with $1.99 \mathrm{mg} \mathrm{L}^{-1}$, caused by the leaching of the sewage from the communities of this region. It is also possible to observe that the water used in the flooded rice crop returns to the Betume river through drainage channels without any form of treatment.

In the dry period, the lowest WQI value (28) was observed in the Jacaré river in the year 2013, being also classified as bad, and 

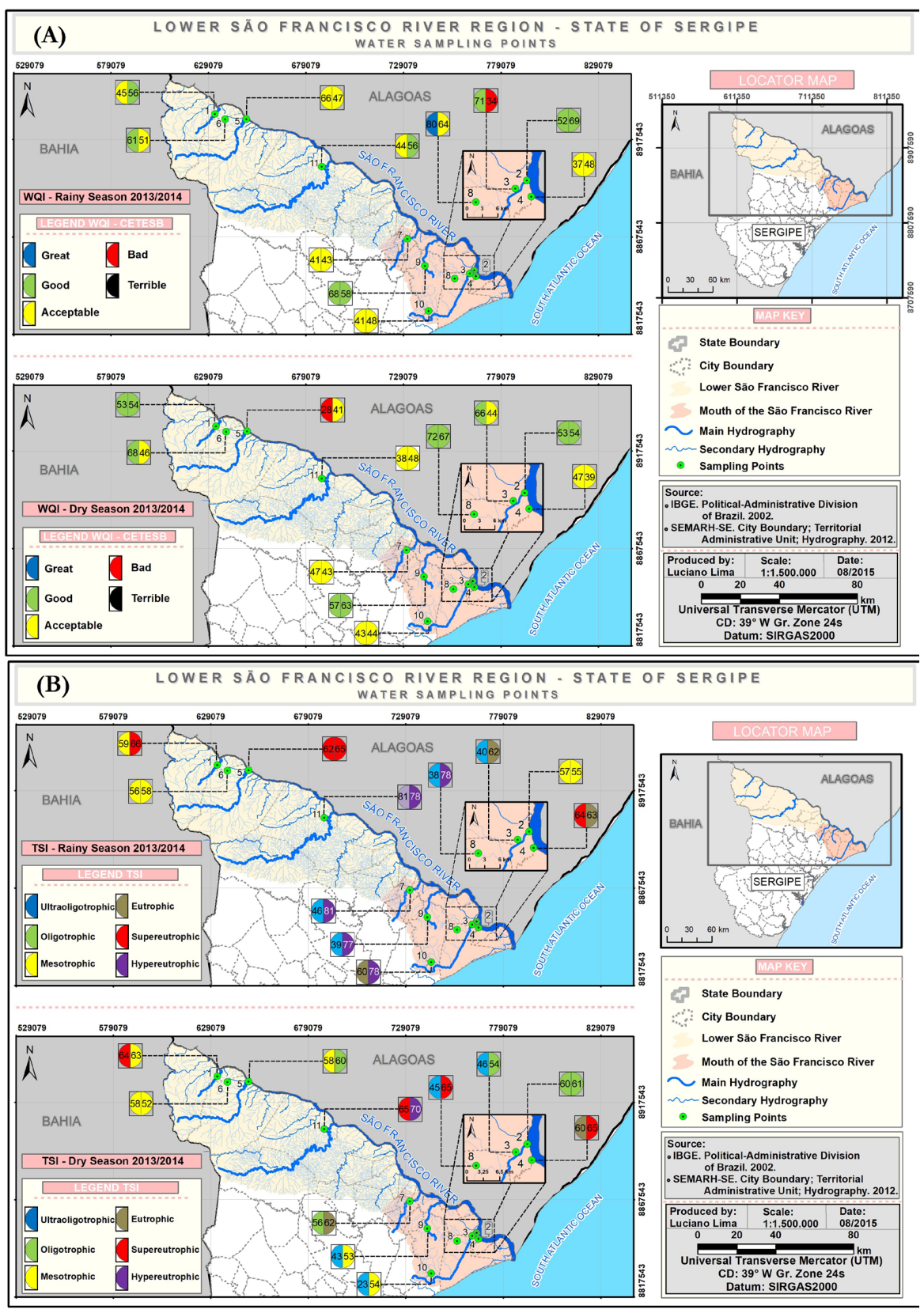

Figure 2. Water quality in the period (rainy and dry) in the years 2013 and 2014 for the main tributaries of the lower São Francisco river (A) Water Quality Index - WQI and (B) Trophic State Index - IET.

this condition may be directly related to the pollution caused by the city of Poço Redondo, which presented significant changes in its parameters coliform, above $1.3 \times 10^{4}(\mathrm{MPN})$, nitrate $\left(10 \mathrm{mg} \cdot \mathrm{L}^{-1}\right)$, Ptotal (0.05 mg.L $\left.\mathrm{L}^{-1}\right)$ and OD (2.25 mg.L $\left.\mathrm{L}^{-1}\right)$, as shown in Figure 2A. During the monitoring of this river, it was possible to observe throughout the study period the presence of a high number of aquatic macrophytes which are possible indicators of the nutrient contribution in the natural system. Some problems resulting from this enrichment by nutrients are the eutrophication process which promote the excessive growth of algae, resulting in an increase in the rate of organic matter decomposition, the reduction of dissolved oxygen and deterioration of water quality (SCHEER; LISBOA; BURDA, 2016).

The enrichment of the water bodies is associated to the increase of primary productivity and the occurrence of excessive development of algae or aquatic macrophylls, and may jeopardize their multiple uses (MAIA; CARVALHO; CARVALHO, 2015).

Regarding trophic state conditions, it is observed, in the rainy season of 2013 , that $36 \%$ of the sources presented a TSI above 60. The Capivara river, which had TSI values of 81 , was classified as hypereutrophic, influenced by the high indexes of Chlorophyll-a and total phosphorus. In 2014, more than $45 \%$ of the springs were hypereutrophic with an TSI above 77 (Figure 2B). 
This condition is directly related to the agricultural activities in the irrigated perimeters which increase the concentrations of phosphorus with the use of agrotoxic and fertilizers. This increase in the contribution of Ptotal in the body of water is justified by the mechanism of surface runoff, often occurring in rainy periods, mainly in soils devoid of vegetation or with a predominance of ground cover, a similar result to those obtained in others work by Aguiar et al. (2015), Alves et al. (2012) and Wiegand, Piedra and Araújo (2016).

However, in the dry season with low rainfall and reduced agricultural activities, 64\% (in 2013) and 36\% (in 2014) of the sources presented a satisfactory TSI. It is worth highlighting that the recovery capacity of water sources is limited, especially when anthropic actions and eutrophication processes are on the rise, compromising water quality both for human consumption and for the conservation of local biodiversity.

After analysis of hierarchical grouping, the dendogram was determined in the rainy and dry period, according to Figure 3. During the rainy season four groups were formed (1,2,3 and 4), Figure 3A. In Group 1, the subgroup formed by A-B-C had a better approximation (20.51) in relation to the subgroup D-E. When comparing the relation between groups it is observed
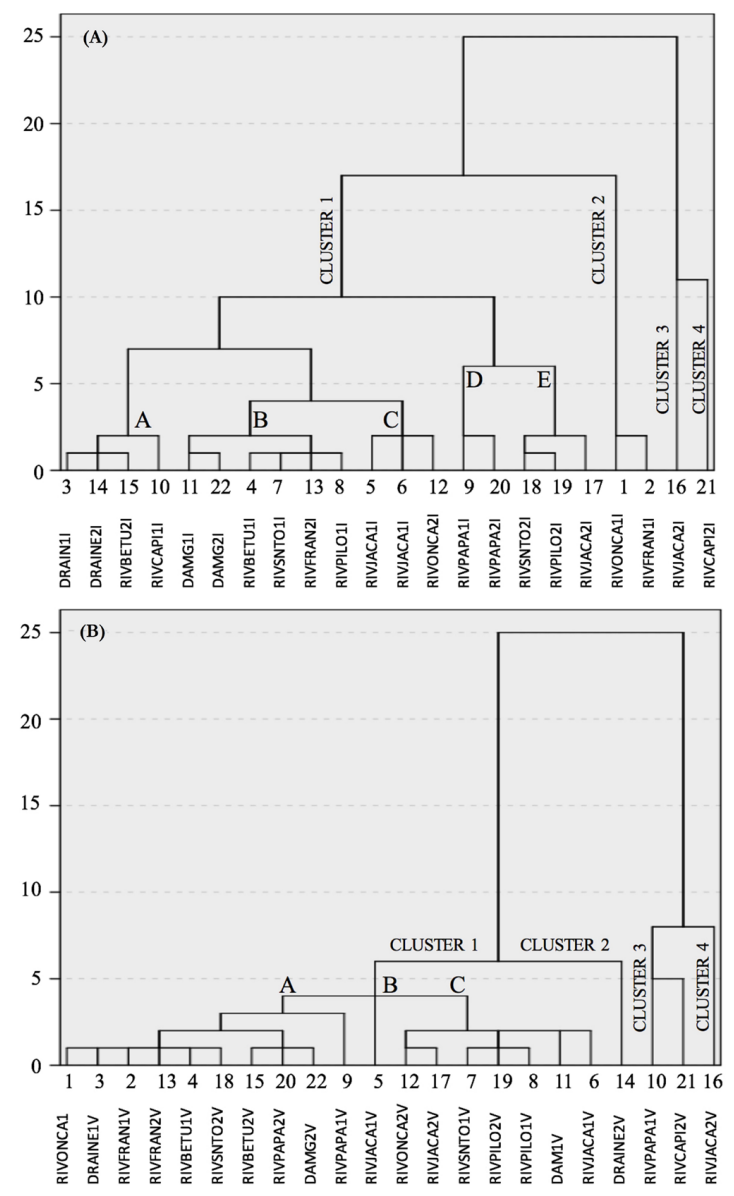

Figure 3. Hierarchical grouping analysis of the variables determined in the rainy season (A) and dry period (B) in the sources of the lower São Francisco river in the years of 2013 (1) and 2014 (2). that groups 1 and 2 had a better approximation (47.71), which characterizes the physicochemical parameters of the springs under study. While, for groups 3 and 4, it is observed a greater distancing (93.75), with tendency of formation of outliers (isolated).

During the monitoring period between 2013 and 2014, the drainage of Betume (3-14), the dam of the Jacaré-Curituba (11-22) and the Papagaios river (9-20), formed by Group 1A, 1B and 1D, respectively, presented greater similarity and approximation. This condition indicates and ratifies a decrease of the anthropic actions in these regions during the monitoring confirmed by the stabilization of the results for the physical-chemical parameters. Still analyzing group 1A, the drainage of Betume (3-14) and Betume river (3-15), located in the same region of the irrigated perimeter, in which the rhiziculture predominates, it is expected an Euclidean approximation of 3.19 between these springs, in most of the physical-chemical parameters analyzed.

Also in the rainy season, the Santo Antônio river (4-7) being a tributary of the Berume river, presented a dendogram of 2.36, with this small distancing, being able to observe a similarity of relation between the parameters $\mathrm{pH}$, total phosphorus, nitrate, ammonia, OD, temperature, chlorophyll-a and TSI. Even when compared with the Pilões river 2013 (4-8) and São Francisco river 2014 (4-13) with the Betume river, the Euclidean distances are 3.43 and 2.37, respectively, demonstrating that there is a similarity to the physical characteristics - chemical and microbiological characteristics of $\mathrm{BOD}, \mathrm{pH}$, total phosphorus, nitrate, ammoniacal nitrogen, temperature and WQI.

For the 2013 Onça stream, which is a tributary of the São Francisco river 2013 (1 - 2), it presented a Euclidean distance of 16.68 , which is a condition of distance, representing changes in physical-chemical and microbiological characteristics. Another similarity of this nature can be seen for Groups 3 and 4, which presents an isolated transition indicating statistically that its variables have different characteristics.

For the monitoring of the springs in the dry period, it was observed in the dendogram, the formation of four groups (Figure 3B). Groups 2 and 4 were considered outlier because they presented a greater distancing, characterizing groups isolated by virtue of their physicochemical parameters being distinct when compared with other groups.

Group 1 was formed by three subgroups which are A-B-C. Among these associations, group 1A formed by the São Francisco river (2-13) presented similarity in its physical-chemical parameters (Figure 3B). The same tendency occurred to the Onça stream and drainage of the Betume (1-3), having the location of its distinct and extreme springs, converge to a Euclidean approximation with a value of 3.14 . Also analyzing the dendogram in the dry period, it is observed that the relation of the Santo Antônio river with the Pilões river (7-19) presented an Euclidean distance of 3.67, which characterizes similar parameters of BOD, OD, $\mathrm{pH}$, total phosphorus, nitrate, ammoniacal nitrogen, temperature, chlorophyll and WQI, located in a semi-humid region. Still in Group 1 , it is possible to compare the Jacaré (5) and the Papagaios rivers (9), which presented a distance of 38.64, showing that besides the remoteness and its isolation, it ratifies that the physical-chemical and microbiological characteristics in the period were different.

Table 5 shows the results of the factorial analysis of the 18 parameters studied, with the temperature being withdrawn because it presents a value with low statistical significance. Thus, in the first factor, the most important variables were electrical 
Table 5. Matrix of factorial analysis of rotated components for water quality variables of the lower São Francisco.

\begin{tabular}{|c|c|c|c|c|c|}
\hline Component & 1 & 2 & 3 & 4 & 5 \\
\hline C. E & 0.98 & 0.04 & 0.09 & 0.15 & -0.03 \\
\hline Chloride & 0.97 & -0.09 & 0.10 & 0.13 & -0.08 \\
\hline Sodium & 0.96 & -0.11 & 0.02 & 0.14 & -0.11 \\
\hline STD & 0.96 & 0.17 & 0.03 & 0.15 & 0.00 \\
\hline Hardness & 0.95 & -0.08 & 0.00 & 0.20 & -0.08 \\
\hline Sulfate & 0.80 & -0.01 & 0.51 & 0.06 & -0.06 \\
\hline $\mathrm{pH}$ & -0.02 & 0.97 & -0.01 & -0.02 & 0.09 \\
\hline OD & -0.02 & 0.95 & 0.01 & -0.04 & -0.13 \\
\hline $\mathrm{DBO}$ & -0.04 & 0.94 & -0.03 & -0.09 & 0.23 \\
\hline Ammonia & 0.18 & -0.06 & 0.91 & 0.01 & 0.02 \\
\hline C. T & 0.09 & -0.12 & 0.88 & 0.17 & 0.08 \\
\hline Nitrate & 0.00 & 0.47 & 0.73 & -0.13 & 0.01 \\
\hline Chlorophyll a & 0.21 & -0.16 & -0.20 & 0.91 & -0.06 \\
\hline TSI & 0.15 & -0.05 & 0.08 & 0.88 & 0.23 \\
\hline $\mathrm{P}$ & 0.35 & 0.02 & 0.31 & 0.84 & -0.04 \\
\hline WQI & 0.04 & -0.04 & -0.19 & -0.29 & -0.86 \\
\hline Turbidity & -0.11 & 0.43 & 0.02 & -0.24 & 0.71 \\
\hline Iron & -0.25 & -0.46 & -0.23 & 0.07 & 0.56 \\
\hline
\end{tabular}

conductivity, total dissolved solids, hardness, anions (chloride, sulfate) and cation (sodium), representing the mineral content of the water, therefore important for the characterization of water of the lower São Francisco river. This factor indicates that the total dissolved solids presented a great contribution in the concentration of the ions, besides, the electrical conductivity is related to STD and hardness (KUMARESAN; RIYAZUDDIN, 2008).

In the second factor, the variables were $\mathrm{pH}, \mathrm{OD}$ and BOD. In addition, it is important to note that the use of organic matter (BOD) is an important factor in the development of organisms which are more adapted to these conditions, but with a tendency to the loss of aquatic biodiversity (ALVARENGA et al., 2012). For the third factor, it is possible to observe the relationship of ammonia, thermotolerant coliform and nitrate in agricultural areas and that the flow of rainwater by the fertilized soils also contributed to the presence of several forms of nitrogen, among them, the nitrate ion, which is one of the limiting nutrients of aquatic life, being able to indicate the possibility of eutrophication of the water body and the ammonia which causes dissolved oxygen consumption of the natural waters to be biologically oxidized and consequently the deterioration of the quality of the body of water.

For the fourth factor, it is observed the relation of TSI with Chlorophyll and Total Phosphorus to evaluate the trophic state of the springs. The eutrophication process consists of an increase in the fertility of the aquatic environments, caused by the excessive intake of nutrients, mainly, total phosphorus and nitrogen. The nutrients come from the different uses of the soils in the vicinity of the hydrographic basins and the increase of their concentrations in the water has the consequence of the loss of its quality (SOUZA; GASTALDINI, 2014).

The fifth factor indicates the relationship of WQI and turbidity, which are inversely proportional, that is, when high turbidity occurs in the springs, the photosynthesis of submerged rooted vegetation and algae is reduced. Such reduced plant development can, in turn, suppress fish productivity by reducing aquatic biological communities. In addition, turbidity can adversely affect the domestic, industrial and recreational uses of water (CETESB, 2008).
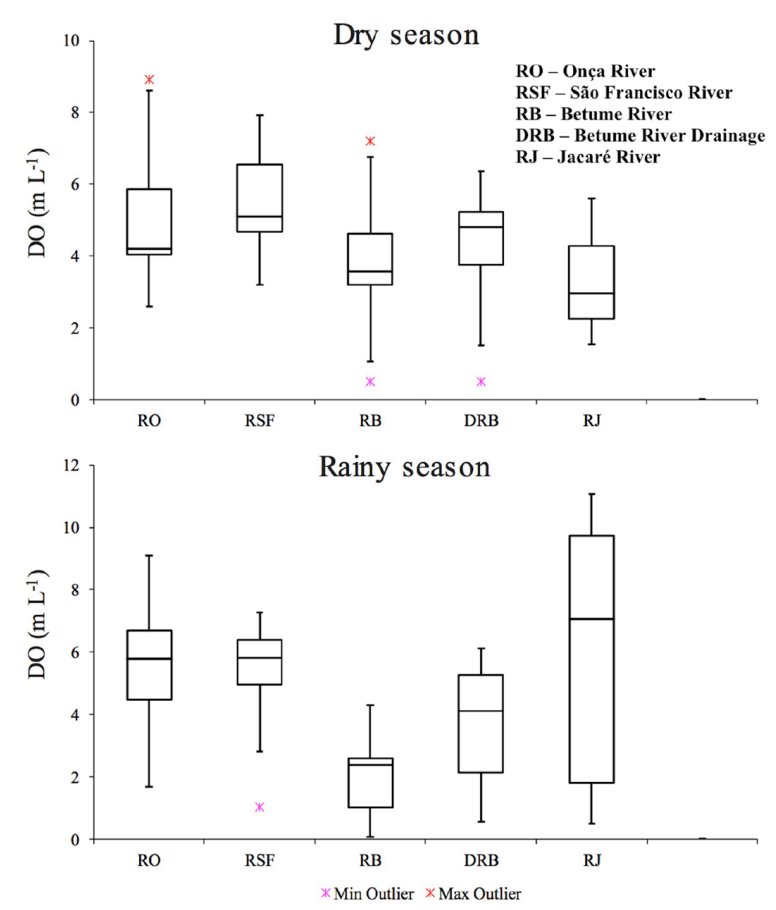

Figure 4. Box-plot graphs depicting OD variations in the dry and rainy season in the main tributaries of the lower São Francisco river.

In Figure 4 to 6, the box-plot graphs of some parameters which show significant differences between the concentrations measured in the dry and rainy period are shown for the main tributaries of the lower São Francisco river (Onça Stream - RO, São Francisco river - RSF, Betume river - RB, Betume Drainage - DRB and Jacaré river - RJ), using the Mann-Whitney statistical test with significance level $\alpha$ of $5 \%$, corroborating the discussion above. The graphs were plotted with an n-sampling (number of collections performed between the years of 2013 and 2014) corresponding to 22 collections. 

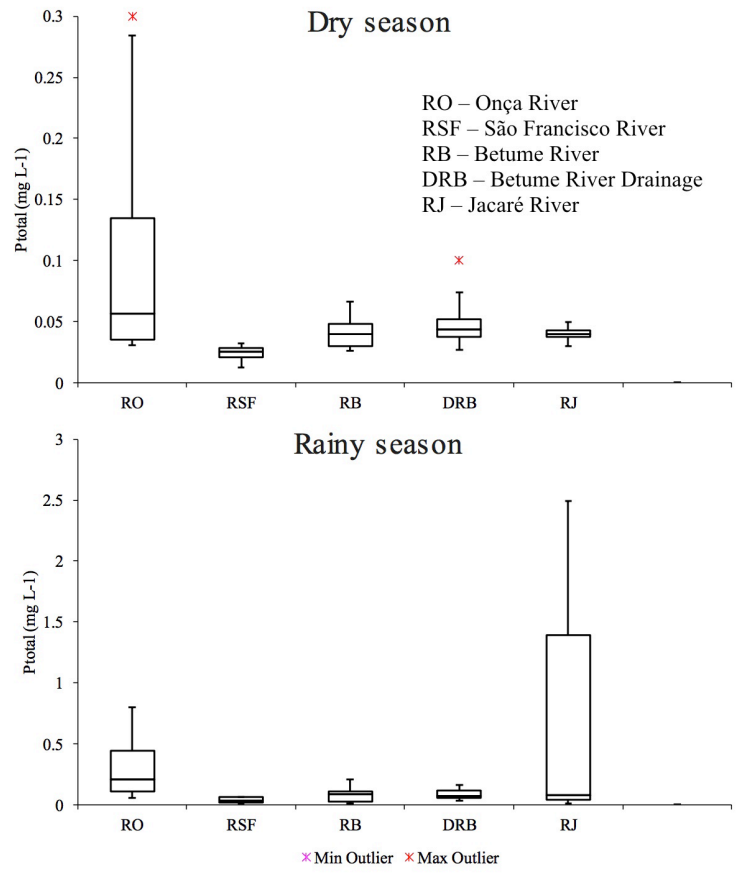

Figure 5. Box-plot graphs representing the total phosphorus variations in the dry and rainy season, in the main tributaries of the lower São Francisco river.

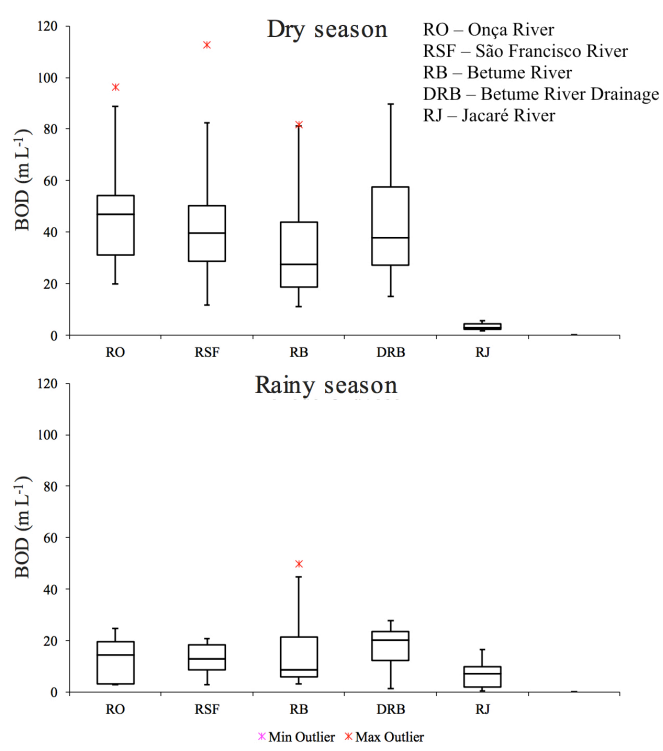

Figure 6. Box-plot graphs representing the BOD variations in the dry and rainy period in the main tributaries of the lower São Francisco river.

The box-plot graphs above (Figure 4) show significant differences when comparing the dry and rainy periods for the dissolved oxygen parameter. In Figure 5, box-plot graphs of Total Phosphorus variations in the dry period ( 0.0 to $0.3 \mathrm{mg} . \mathrm{L}^{-1} \mathrm{scale}$ ) and rainy scale ( 0.0 to $\left.3.0 \mathrm{mg} . \mathrm{L}^{-1}\right)$, in the main tributaries of the lower São Francisco river.
One of the main sources of phosphorus in the aquatic environment is the entrance of this nutrient due to the drainage basin (MARQUES, 2006), the author reports that in the reservoir of the Luís Eduardo Magalhães hydroelectric plant, in the Tocantins, phosphorus concentration at the apex of the rainy season was verified. In the Velhas river basin, a significant difference was observed for this parameter between the dry and rainy periods, and the highest concentrations were found in the rainy season (PONTES; MARQUES; MARQUES, 2012).

The increase in phosphorus concentrations in the bottom of rivers and lakes can be explained by the sedimentation of "algae" particles and by the sedimentation of particulate phosphorus (TIECHER et al., 2017).

BOD values indicate the extent of organic pollution in aquatic systems, which negatively affect water quality. In this work the BOD values ranged from 2.7 to $112.0 \mathrm{mg} . \mathrm{L}^{-1}$, with the highest values found in the dry season. The box-plot graph for the biochemical oxygen demand (BOD), Figure 6, shows a variation of the values in relation to the dry and rainy period, probably due to the concentration of organic matter in the body of water from the common evapotranspiration in the region in this dry period, it can be observed that there is an increase of the BOD values also in the period before the beginning of the rainy season, this fact is common due to the increase of the organic matter content in the water, consequence of the "washing of surfaces", both in the urban and rural areas, since there is consumption of dissolved oxygen for the stabilization of organic matter.

When comparing OD and DBO values for dry and rainy seasons (Figures 4 and 6), it is evident that BOD is inversely proportional to OD, that is, the lower amount of oxygen present in the aquatic environment stimulated by organic matter will promote higher BOD rates (LATUF, 2004).

It is understood, therefore, that the higher the BOD, the greater the degree of water pollution (ALVES, 2009). A high BOD value may indicate an increase in microflora present and interfering with the equilibrium of aquatic life, as well as produce unpleasant tastes and odors, and may obstruct the sand filters used in water treatment plants (GOMES; SILVA; PESSOA, 2007).

Higher concentrations of pollutants due to seasonality are described in the literature. For the total coliform parameters (AZEVEDO LOPES; MAGALHÃES JÚNIOR, 2010; CHAVES; SANTOS, 2009), DBO (DONADIO; GALBIATTI; PAULA, 2005; VASCO et al., 2011), nitrite (BERKA; SCHREIER; HALL, 2001) turbidity, total solids (RÍOS-VILLAMIZAR; MARTINS JUNIOR; WAICHMAN, 2011; AZEVEDO LOPES; MAGALHÃES JÚNIOR, 2010), the authors report higher concentrations in the rainy season. According to Grossi (2006), the vicinal roads and carriages serve as a pathway for surface runoff, causing erosive processes, which intensify in the rainy season due to the increase in the amount and speed of flow.

As already mentioned, the values of TSI in the rainy season are worse because there is an increase of these pollutants carried to the bodies of water, which corroborates with the results obtained. 


\section{CONCLUSION}

The low WQI values for the evaluated springs show a tendency to the degradation of the water quality due to the anthropic actions in the rainy and dry periods. The values of physical-chemical parameters, such as OD, thermotolerant coliforms and nitrate in the Betume and Jacaré rivers do not meet the Class 2 quality standard of CONAMA 357/2005 (BRASIL, 2005).

The values found for the TSI showed a compromise in the water quality through the eutrophication of the springs, mainly in relation to the concentrations of Ptotal and Chlorophyll-a, these values, above the parameters of CONAMA 357/2005, for the Jacaré river, Santo Antonio, Pilões river, Papagaio river and Capivara river. The high values of TSI in the rainy season are related to the agricultural activities of the irrigated perimeters, which contributes to the degradation of the environment.

During the rainy season, the cluster analysis showed an association between the physical-chemical parameters of the Betume river and the other rivers: Santo Antônio river, Pilões river and São Francisco river. This is statistically due to the Euclidean square distance smaller than 3.5, which indicates a trend of similarity of physical-chemical and microbiological characteristics. In the same way, this relation of association occurred during the dry period, in the Onça stream with Betume drainage; in the Santo Antonio river with Pilões river, presented Euclidean proximities with distances smaller than 3.7.

The application of the Factor Analysis to the set of variables resulted in the selection of five factors indicating the water quality of the low San Francisco springs monitored, explaining 89.17\% of the total variance. With the Varimax orthogonal rotation of the factors, it was observed that the water quality variables are mainly related to mineral content, organic matter, surface runoff and degree of pollution.

It ought to be emphasized that the results of this work aim to guide the optimization of the use of financial resources that should be applied to the monitoring of these springs, not necessarily their reduction. The techniques of hierarchical grouping associated with the samples to compare the different sources of contamination of each spring were used and showed promising results. However, the optimization of the monitoring network ought to take into account the concentration trends of the parameters, the history of the results, and especially, the technical and specific knowledge of the managing body, who should decide the possibility of changes in sampling frequency.

\section{ACKNOWLEDGEMENTS}

To the Secretariat of State for the Environment and Water Resources of the State of Sergipe (SEMARH), a collaborating agency in the supply of physicochemical and microbiological parameters of some tributaries of the São Francisco river, which enabled the execution of this work.

\section{REFERENCES}

AGUIAR, C.; PELEJA, J.; SOUSA, K.; GOCH, Y.; GUIMARÃES, A. Nivel de trofia em microbacias hidrográficas sob diferentes usos de solo, na região amazônica. Revista Brasileira de Recursos Hídricos, v. 20, n. 4, p. 1093-1102, 2015. http://dx.doi.org/10.21168/rbrh. v20n4.p1093-1102.

ALVARENGA, L. A.; MARTINS, M. P. P.; CUARTAS, L. A.; PENTEADO, V. A.; ANDRADE, A. Estudo da qualidade e quantidade da água em microbacia, afluente do Rio Paraíba do Sul - São Paulo, após ações de prevenção ambiental. Revista Ambiente \& Água, v. 7, n. 3, p. 228-240, 2012. http://dx.doi.org/10.4136/ ambi-agua. 987.

ALVES, E. C. R. F. Monitoramento quali-quantitativo da bacia bidrográfica do Rio Coxipó - MT: uma ferramenta para implementação da Gestão Participativa dos Recursos Hídricos. 2009. 255 f. Dissertação (Mestrado em Física Ambiental) - Universidade Federal de Mato Grosso, Cuiabá, 2009. Disponível em: < http://www.dominiopublico. gov.br/pesquisa/DetalheObraDownload.do?select_action $=\& \mathrm{CO}_{-}$ obra=144322\&co_midia=2>. Acesso em: 24 out. 2017.

ALVES, I. C. C.; EL-ROBRINI, M.; SANTOS, M. L. S.; MONTEIRO, S. M.; BARBOSA, L. P. F.; GUIMARÃES, J. T. F. Qualidade das águas superficiais e avaliação do estado trófico do Rio Arari (Ilha de Marajó, norte do Brasil). Acta Amazonica, v. 42, n. 1, p. 115-124, 2012. http://dx.doi.org/10.1590/S0044-59672012000100014.

AMORIM, D. G.; CAVALCANTE, P. R. S.; SOARES, L. S.; AMORIM, P. E. C. Enquadramento e avaliação do índice de qualidade da água dos igarapés Rabo de Porco e Precuá, localizados na área da Refinaria Premium I, município de Bacabeira (MA). Engenharia Sanitaria e Ambiental, v. 22, n. 2, p. 251-259, 2016. http://dx.doi. org/10.1590/s1413-41522016131212.

ANDRADE, E. M.; AQUINO, D. N.; LUNA, N. R. S.; LOPES, F. B.; CRISÓSTOMO, L. A. Dinâmica do nível freático e da salinização das águas subterrâneas em áreas irrigadas. Revista Ceres, v. 63, n. 5, p. 621-630, 2016. http://dx.doi.org/10.1590/0034-737x201663050005.

ANDRIETTI, G.; FREIRE, R.; AMARAL, A. G.; ALMEIDA, F. T.; BONGIOVANI, M. C.; SCHNEIDER, R. M. Índices de qualidade da água e de estado trófico do rio Caiabi, MT. Revista Ambiente \& Água, v. 11, n. 1, p. 162-175, 2016. http://dx.doi.org/10.4136/ ambi-agua.1769.

AZEVEDO LOPES, F. W.; MAGALHÃES JÚNIOR, A. P. M. Influência das condições naturais de $\mathrm{pH}$ sobre o índice de qualidade das águas (IQA) na bacia do Ribeirão de Carrancas. Geografias, v. 6, n. 2, p. 134-147, 2010.

AZHAR, S. C.; ARIS, A. Z.; YUSOFF, M. K.; RAMLI, M. F; JUAHIR, H. HAFIZAN, J. Classification of river water quality using multivariate analysis. Procedia Environmental Sciences, v. 30, p. 79-84, 2015. http://dx.doi.org/10.1016/j.proenv.2015.10.014.

BARRETO, L. V.; FRAGA, M. D. S.; BARROS, F. M.; ROCHA, F. A.; AMORIM, J. D. S.; CARVALHO, S. R.; BONOMO, P.; SILVA, D. P. Relação entre vazão e qualidade da água em uma seção de rio. Revista Ambiente \& Água, v. 9, n. 1, p. 118-129, 2014. http://dx.doi. org/10.4136/ambi-agua.1278. 
BERKA, C.; SCHREIER, H.; HALL, K. Linking water quality with agricultural intensification in a rural watershed. Water, Air, and Soil Pollution, v. 127, n. 1-4, p. 389-401, 2001. http://dx.doi. org/10.1023/A:1005233005364.

BRASIL. Ministério do Desenvolvimento Urbano e Meio Ambiente. Conselho Nacional do Meio Ambiente - CONAMA. Resolução $\mathrm{n}^{\circ} 357$, de 17 de março de 2005. Dispõe sobre a classificação dos corpos de água e diretrizes ambientais para o seu enquadramento, bem como estabelece as condições e padrões de lançamento de efluentes, e dá outras providências. Diário Oficial [da] República Federativa do Brasil, Brasília, DF, 17 mar. 2005. Disponível em: < http:/ /www. mma.gov.br>. Acesso em: 10 jan. 2016.

CETESB - COMPANHIA AMBIENTAL DO ESTADO DE SÃO PAULO. Relatório de qualidade das águas interiores do Estado de São Paulo. São Paulo, 2008. Disponível em: <www.cetesb.sp.gov. br>. Acesso em: 10 maio 2016.

CHAVES, H. M. L.; SANTOS, L. B. Ocupação do solo, fragmentação da paisagem e qualidade da água em uma pequena bacia hidrográfica. Revista Brasileira de Engenharia Agrícola e Ambiental, v. 13, p. 922-930, 2009. Suplemento. http://dx.doi.org/10.1590/S1415-43662009000700015.

CRUZ, C. D.; FERREIRA, F. M.; PESSONI, L. A. Biometria aplicada ao estudo da diversidade genética. Visconde do Rio Branco: Suprema, 2011. 620 p.

CUNHA, R. W.; GARCIA JUNIOR, M. D. N.; ALBERTONI, E. F; PALMA-SILVA, C. Qualidade de água de uma lagoa rasa em meio rural no sul do Brasil. Revista Brasileira de Engenharia Agrícola e Ambiental, v. 17, n. 7, p. 770-779, 2013. http://dx.doi.org/10.1590/ S1415-43662013000700012.

DONADIO, N. M. M.; GALBIATTT, J. A.; PAULA, R. C. Qualidade da água de nascentes com diferentes usos do solo na bacia hidrográfica do córrego Rico, São Paulo, Brasil. Engenharia Agrícola, v. 25, n. 1, p. 115-125, 2005. http://dx.doi.org/10.1590/ S0100-69162005000100013.

FERREIRA, K. C. D.; LOPES, F. B.; ANDRADE, E. M.; MEIRELES, A. C. M.; SILVA, G. S. Adaptação do índice de qualidade de água da National Sanitation Foundation ao semiárido brasileiro. Revista Ciência Agronômica, v. 46, n. 2, p. 277-286, 2015. http://dx.doi. org/10.5935/1806-6690.20150007.

FIGUEIREDO FILHO, D. B.; SILVA JÚNIOR, J. A. D. Visão além do alcance: uma introdução à análise fatorial. Revista Opinião, v. 16, n. 1, p. 160-185, 2010. http://dx.doi.org/10.1590/S010462762010000100007.

GOMES, N. S.; SILVA, G. A.; PESSOA, A. R. N. Estudo de parâmetros químicos nas águas do Rio Imbassaí no trecho do munícipio de Dias d'Ávila - BA. Candombá Revista Virtual, v. 3, n. 1, p. $1-14,2007$.

GROSSI, C. H. Diagnóstico e monitoramento ambiental da microbacia bidrográfica do rio Queima-Pé (MT). 2006. 122 f. Tese (Doutorado em
Ciências Agronômicas) - Universidade Estadual Paulista "Júlio de Mesquita Filho", Botucatu, 2006.

HAIR, J. F.; ANDERSON, R. E.; TATHAM, R. L.; BLACK, W. C. Análise multivariada de dados. Tradução Adonai S. Sant'Anna e Anselmo C. Neto. 5. ed. Porto Alegre: The Bookman, 2005.

HOSSAIN, M. G.; SELIM REZA, A. H. M.; LUTFUN-NESSA, M.; AHMED, S. S. Factor and cluster analysis of water quality data of the groundwater wells of Kushtia, Bangladesh: implication for arsenic enrichment and mobilization. Journal of the Geological Society of India, v. 81, n. 3, p. 377-384, 2013. http://dx.doi.org/10.1007/ s12594-013-0048-0.

KUMARESAN, M.; RIYAZUDDIN, P. Factor analysis and Linear Regression Model (LRM) of metal speciation and physico-chemical characters of groundwater samples. Environmental Monitoring and Assessment, v. 138, n. 1-3, p. 65-79, 2008. http://dx.doi.org/10.1007/ s10661-007-9761-8. PMid:17508262.

LAMPARELLI, M. C. Grau de Trofia em corpos d'água do Estado de São Paulo: avaliação dos métodos de monitoramento. 2004. 235 f. Tese (Doutorado em Ciências) - Universidade de São Paulo, São Paulo, 2004. Disponível em: <www.teses.usp.br/ teses/disponiveis /41/.../ Tese Lamparelli2004.pdf>. Acesso em: 5 jul. 2016.

LATUF, M. O. Diagnóstico das Águas Superficiais do Córrego São Pedro, Juiz de Fora-MG. Revista Geografia, v. 13, n. 1, p. 18-55, 2004.

LIMA, C. R. N.;ZEILHOFER, P.; DORES, E.; CRUZ, I V Variabilidade espacial da qualidade de água em escala de bacias - Rio Cuiabá e São Lourenço, Mato Grosso. Revista Brasileira de Recursos Hídricos, v. 20, n. 1, p. 169-178, 2015. http://dx.doi.org/10.21168/rbrh. v20n1.p169-178.

LIMA, M. O.; SANTOS, E. C. O.; JESUS, I. M.; MEDEIROS, A. C.; FAIAL, K. C. F.; ALVES, C. N. Assessment of Surface Water in Two Amazonian Rivers Impacted by Industrial Wastewater, Barcarena City, Pará State (Brazil). Journal of the Brazilian Chemical Society, v. 22, n. 8, p. 1493-1504, 2011. http://dx.doi.org/10.1590/ S0103-50532011000800013.

MAIA, A. A. D.; CARVALHO, S. L.; CARVALHO, F. T. Comparação de dois índices de determinação do grau de trofia nas águas do Baixo Rio São José dos Dourados, São Paulo, Brasil. Engenharia Sanitaria e Ambiental, v. 20, n. 4, p. 613-622, 2015. http://dx.doi.org/10.1590/ S1413-41522015020040121258.

MARQUES, A. K. Análise da diversidade fitoplanctônica no reservatório da Usina Hidroelétrica Luís Eduardo Magalhães, no médio Tocantins - TO: estrutura da comunidade, flutuações Temporais e espaciais. 2006. 157 f. Dissertação (Mestrado em Ciências do Ambiente) - Universidade Federal de Tocantins, Palmas, 2006.

MARTINS, D. M. F.; CHAGAS, R. M.; MELO NETO, J. O.; MÉLLO JÚNIOR, A. V. Impactos da construção da usina hidrelétrica de Sobradinho no regime de vazões no Baixo São Francisco. Revista Brasileira de Engenharia Agricola e Ambiental Campina Grande, v. 15, 
n. 10, p. 1054-1061, 2011. http://dx.doi.org/10.1590/S141543662011001000010 .

MASSOUD, M. A. Assessment of water quality along arecreational section of the Damour River in Lebanon usingthe water quality index. Environmental Monitoring and Assessment, v. 184, n. 7, p. 4151-4160, 2012. http://dx.doi.org/10.1007/s10661-011-2251-z. PMid:21853414.

MORETTO, D. L.; PANTA, R. E.; COSTA, A. B.; LOBO, E. A. Calibration of water quality index (WQI) based on Resolution $\mathrm{n}^{\circ}$ $357 / 2005$ of the Environment National Council (CONAMA). Acta Limnologica Brasiliensia, v. 24, n. 1, p. 29-42, 2012. http:/ /dx.doi. org/10.1590/S2179-975X2012005000024.

NONATO, E. A.; VIOLA, Z. G. G.; ALMEIDA, K. C. B.; SCHOR, H. H. R. Tratamento estatístico dos parâmetros da qualidade das águas da bacia do alto curso do Rio das Velhas. Química Nova, v. 30, n. 4, p. 797-804, 2007. http://dx.doi.org/10.1590/S010040422007000400008.

OLIVEIRA, C. N.; CAMPOS, V. P.; MEDEIROS, Y. D. P. Avaliação e identificação de parâmetros importantes para a qualidade de corpos d'água no semiárido baiano. Estudo de caso: bacia hidrográfica do rio Salitre. Quimica Nova, v. 33, n. 5, p. 1059-1066, 2010. http:// dx.doi.org/10.1590/S0100-40422010000500010.

PONTES, P. P.; MARQUES, A. R.; MARQUES, G. F. Efeito do uso e ocupação do solo na qualidade da água na micro-bacia do Córrego Banguelo - Contagem. Ambi-Agua, v. 7, n. 3, p. 183-194, 2012. http://dx.doi.org/10.4136/ambi-agua.962.

RÍOS-VILLAMIZAR, E. A.; MARTINS JUNIOR, A. F; WAICHMAN, A. V. Caracterização físico-química das águas e desmatamento na bacia do rio Purus, Amazônia Brasileira Ocidental. Revista Geografia Acadêmica, v. 5, n. 2, p. 54-65, 2011.

ROCHA, C. H. B.; COSTA, H. F. Variação temporal de parâmetros limnológicos em manancial de abastecimento em Juiz de Fora, MG. Revista Brasileira de Recursos Hídricos, v. 20, n. 2, p. 543-550, 2015. http://dx.doi.org/10.21168/rbrh.v20n2.p543-550.

ROCHA, C. H. B.; PEREIRA, A. M. Análise multivariada para seleção de parâmetros de monitoramento em manancial de Juiz de Fora, Minas Gerais. Revista Ambiente \& Água, v. 11, n. 1, p. 176-187, 2016. http://dx.doi.org/10.4136/ambi-agua.1590.

SALAH, E. A. M.; TURKI, A. M.; AL-OTHMAN, E. M. Assessment of water quality of Euphrates river using cluster analysis. Journal of Environmental Protection, v. 3, n. 12, p. 1629-1633, 2012. http:// dx.doi.org/10.4236/jep.2012.312180.

SCHEER, M. B.; LISBOA, A. M.; BURDA, T. M. Rendimentos operacionais de barco removedor e escavadeira de braço longo no controle de infestações de plantas aquáticas no reservatório Piraquara II, Paraná, Brasil. Revista Brasileira de Recursos Hídricos, v. 21, n. 2, p. 328-337, 2016. http://dx.doi.org/10.21168/rbrh.v21n2.p328-337.

SOUZA, M. M.; GASTALDINI, M. C. C. Avaliação da qualidade da água em bacias hidrográficas com diferentes impactos antrópicos.
Engenharia Sanitaria e Ambiental, v. 19, n. 3, p. 263-274, 2014. http:/ / dx.doi.org/10.1590/S1413-41522014019000001097.

TIECHER, T.; SCHENATO, R. B.; SANTANNA, M. A.; CANER, L.; SANTOS, D. R. Phosphorus forms in sediments as indicators of anthropic pressures in an agricultural catchment in Southern Brazil. Revista Brasileira de Ciência do Solo, v. 41, 2017. http://dx.doi. org/10.1590/18069657rbcs20160569.

VASCO, A. N.; BRITTTO, F. B.; PEREIRA, A. P. S.; MÉLLO JÚNIOR, A. V. M.; GARCIA, C. A. B.; NOGUEIRA, L. C. Avaliação espacial e temporal da qualidade da água na sub-bacia do rio Poxim, Sergipe, Brasil. Ambi-Agua, v. 6, n. 1, p. 118-130, 2011. http://dx.doi.org/10.4136/ambi-agua.178.

VASCONCELOS, V. M. M.; SOUZA, C. F. Caracterização dos parâmetros de qualidade da água do manancial Utinga, Belém, PA, Brasil. Ambi-Agua, v. 6, n. 2, p. 305-324, 2011. http://dx.doi. org/10.4136/ambi-agua.202.

WIEGAND, M. C.; PIEDRA, J. I. G.; ARAÚJO, J. C. Vulnerabilidade à eutrofização de dois lagos tropicais de climas úmido (Cuba) e semiárido (Brasil). Engenharia Sanitaria e Ambiental, v. 21, n. 2, p. 415-424, 2016. http://dx.doi.org/10.1590/s1413-41522016139527.

WITTMAN, J.; WECKWERTH, A.; WEISS, C.; HEYER, S.; SEIBERT, J.; KUENNEN, B.; INGELS, C.; SEIGLEY, L.; LARSEN, K.; ENOS-BERLAGE, J. Evaluation of land use and water quality in an agricultural watershed in the USA indicates multiple sources of bacterial impairment. Environmental Monitoring and Assessment, v. 185 , n. 12, p. 10395-10420, 2013. http://dx.doi.org/10.1007/ s10661-013-3340-y. PMid:23873513.

\section{Authors contributions}

Fábio Brandão Britto: Contributed to the conception of the work, execution of monitoring, data acquisition and treatment, discussion and writing of the paper.

Anderson Nascimento do Vasco: Participated in the execution of the monitoring, acquisition and treatment of data, discussion and writing of the paper.

Antenor de Oliveira Aguiar Netto: Contributed to the design, discussion, data analysis, review and writing of the paper.

Carlos Alexandre Borges Garcia: Contributed to the discussion, review, submission and writing of the paper.

Gilsia Fabiane Oliveira Moraes: Contributed to the discussion, review and writing of the paper.

Marinoé Gonzaga da Silva: Contributed to the data analysis, revision and writing of the paper. 